\title{
COLOURED STICK: TEACHING WITH A COMPREHENSIVE GAME FOR IMPROVING CHILDREN'S SOCIAL-EMOTIONAL ABILITY IN KINDERGARTEN
}

\author{
Author: \\ Sri Tatminingsih (Ph.D.) \\ Universitas Terbuka, \\ (Jakarta, Indonesia) \\ Email: \\ tatmi@ecampus.ut.ac.id
}

Lectors:

\author{
Prof. Drs. Udan Kusmawan, M.A., Ph.D. \\ Universitas Terbuka \\ (Jakarta, Indonesia)
}

Prof. Dr. Atwi Suparman, M.Sc.

Universitas Terbuka

(Jakarta, Indonesia)

Tatminingsih, S. (2019): Coloured Stick: Teaching with a comprehensive game for improving children's social-emotional ability in kindergarden. Különleges Bánásmód, 5. (1). 59-65. DOI 10.18458/KB.2019.1.59

\begin{abstract}
Absztrakt
Emotional ability must be properly managed in order to survive and adapt to social life so that social and emotional abilities can be trained from an early age. As a part of early childhood, kindergarten is one of the most effective places to help children develop social and emotional abilities effectively through play activities. Thus, kindergarten teachers need to find alternative activities and play equipment that can stimulate socio-emotional abilities. One way is by means of the game "Coloured Stick" made of pieces of wood that is developed by combining three types of games, namely constructive games, educational games and traditional games. This teaching tool can be applied in an integrated manner in kindergarten learning activities, which include the opening, core, and cover with a strategy that varies according to the indicators of social-emotional development. The learning process is the use of the game "Coloured Stick" which is systematically designed and integrated so as to facilitate its application. The application of this tool was tested in small groups of 8 students over eight meetings in July and August 2015, and a large group of 14 students over 12 meetings in August and September 2015 in Fithria Islamic Kindergarten, South Jakarta. Subjects in the test groups were teachers and the kindergarten students. The results of both the trial groups were seen from the difference between initial and final assessment. The small trial group results increased by 0.1 points $(4.88 \%)$ up to 0.29 points $(9.76 \%)$ whereas the large trial group results increased by 0.05 points $(1.63 \%)$ to 0.93 points $(30.83 \%)$. Descriptive this increase occurred in the child are varied and each child's progress in socio-emotional capabilities in the grain or indicators of social-emotional abilities are different. This is very possible because each child has differing ability to absorb the learning content. The results show that the colored sticks game tool can help children develop social skills because the learning process can be carried out in groups. In addition to boosting the child's emotional development, it can also help children develop confidence and respect for themselves, not become easily frustrated because the concepts are according to the age and development of the children, and to exercise patience because they have to wait for their turn to play.
\end{abstract}

Keywords: Coloured Stick, Comprehensive Game, Children's Social-Emotional Ability, Kindergarten, Diszciplin: pedagogy

\section{Absztrakt}

ÓVODÁS KORÚ GYERMEKEK SZOCIO-EMOCIONÁLIS KÉPESSÉGEINEK ÁTFOGÓ FEJLESZTÉSE A COLOURED STICK/ SZÍNES RUDAK NEVÜ JÁTÉK SEGÍTSÉGÉVEL

Az érzelmi képességet megfelően kell irányítani a túlélés és a társas élethez való alkalmazkodás érdekében, így ezen készségek fejlesztése kora gyermekkortól szükséges. Kora gyerekkorban az óvoda a játéktevékenységeken keresztül az egyik legmegfelelőbb hely a gyermek társas és érzelmi képességeinek fejlesztésére Éppen ezért az óvodapedagógusoknak meg kell találniuk azokat a tevékenységeket és játékeszközöket, melyek a gyermekek társas és érzelmi képességeire jótékonyan hatnak. Az egyik lehetőség erre a Coloured Stick/Színes rudak nevú fából készült játék, amely három játékot ötvöz: konstruktív, oktatási célú és hagyományos játék. Az eszköz alkalmazható az óvodai tanulási tevékenységek során. A játék használata maga a tanulási folyamat. A játék alkalmazását nyolcfős gyerekcsoportban vizsgáltuk nyolc 
megfigyelés során 2015 júliusában és augusztusában, majd egy nagyobb, 14 főből álló csoportban 12 alkalommal 2015 augusztusában és szeptemberében. A vizsgálatot a Fithria Islamic Kindergarten-ben [Fithria Iszlám Óvoda], Jakarta déli részén végeztük. Az eredmények a kezdeti állapot és a záró értékelés között megmutatkoznak. A kisebb, próbacsoport eredményei 0.1 -ról (4.88\%) 0.29-ra nőttek (9.76\%), míg a nagyobb csoportban 0.05 -ről (1.63\%) 0.93 -ra (30.83\%) emelkedtek a mutatók. A növekedés a gyerekek körében változó, mert minden gyermek érzelmi és társas képességeinek fejlődése a társas-érzelmi képességek indikátorainak tükrében más és más. Ez azért lehetséges, mert minden gyermeknek eltérőek a képességei a tanulási tartalom befogadására. Az eredmények azt mutatjk, hogy a színes rudak játék segíthet a gyermekek társas készségeinek fejlesztésében, mert a tanulási folyamat csoportokban zajlik. Ezen kívül a játék elősegíti a gyermek érzelmi fejlődését, ami segít a gyermeknek magabiztosabbá válni és tiszteletet kivívni társai körében. A gyermek nem válik könnyen frusztrálttá a játék felépítésének következében, hiszen a játék igazodik a gyermekek életkorához és feljettségi szintjéhez. A gyermekek a türelmüket is fejleszthetik, mert meg kell várniuk, mikor következnek a játékban.

Kulcsszavak: Coloured Stick /Színes rudacskák, óvoda, gyermekek szocio-emocionális képessége, fejlesztójáték

Diszciplína: pedagógia

\section{INTRODUCTION}

Emotional ability is the ability of person and must be properly managed in order to survive and adapt to social life. Therefore, children should receive emotional training from an early age. As an early childhood institution, kindergarten is the most effective place to help children to develop their social and emotional abilities effectively through play activities.

Social-emotional ability can be translated into the ability to manage emotions and social skills. Both abilities influence each other. Emotions are feelings inside a human which can be happy or unhappy, good or bad. According to the Indonesian dictionary, emotions are the expression of feelings that grow and recede in a short time; a condition of physiological and psychological reactions, such as joy, sadness, compassion, love or the meaning of courage is subjective. Goleman (1995) states that emotion refers to a feeling or thoughts trademark or a state of biological and psychological as well as a series of tendencies to act. According to Syamsu Jospeh (2014), socialization by Sue Ann Robinson Ambron is a learning process that guides children to develop social personality so they will become responsible (Syamsu Joseph, 2014).

Recently this development activity in kindergarten already done varies and integrated, the meaning is the activities in kindergarten are interrelated and interconnected to developing the potential of the children. However, based on the results of preliminary research conducted in October 2014 (Sri Tatminingsih, 2015) to the development activities in Fithria Islamic Kindergarten, South Jakarta, it shows that the development activities of social- emotional ability are not directly done as activities aimed at developing these capabilities, but only as a hidden part of the execution of daily activities. It was seen that the indicator of the development activity is not explicitly listed in the daily learning strategy or design of Daily Activity Plan and the strategy of weekly activities or Weekly Activity Plan. For example, in free play activities, socioemotional abilities develop cooperation, patience to wait their turn and learning how to careless that. Ability is not listed as a primary goal in Daily Activity Plan and Weekly Activity Plan, although in practice this capability is important to be developed in kindergarten. Therefore, the kindergarten teachers need to find alternative activities and play equipment that can stimulate children's socialemotional abilities.

Although social skills and emotional abilities are separate, both are interrelated and influence each other. Laura E Berk $(2006,396$.) claimed that children are the emotional signals such as smiling, crying and being attentive, and are believed to powerfully influence others. In other words, the children's emotional reactions are influenced by the behavior of others (Berk Laura E, 2006, 396)

Good social-emotional ability is an ability that children need to have from a young age because this behavior will influence and determine the ability of children in the future. Children with fragile social behavior will hinder the development of other children as success in life is not only influenced by only cognitive ability, but also by how well individuals can interact with others. The success of an individual is also determined by the success of the individual's interaction with others. 
Socio-emotional capabilities that have been developed since the child is still small will positively contribute to the process of development or child interaction with others in the future. (Ernawulan Saodih, 2015, 31-31.)

Domain social-emotional abilities were systematically designed by Yusuf $(2014,113-114)$ as shown below (Table 1.).

This article is part of the dissertation composed by Sri Tatminingsih, with the title "Development of Comprehensive Games Based Learning Model to Improve Cognitive Ability and Social-emotional (Research and development in Kindergarten in South Jakarta, 2015)".

Based on these concepts, it can be said that the synthesis of socio-emotional abilities is the ability to become social beings the behavior demonstrated in social demands in accordance with the norms, values or social expectations of the surrounding community and the ability to respond or react, and manage your thoughts and feelings through biological changes that can be observed directly to an event that faced both inside and outside of himself.

Comprehensive Game or Plaything comprehensive (Sri Tatminingsih, 2015) is a tool created by combining three types of games, namely constructive games, educational games and traditional games.

Constructive play is a form of the game where children use the material to create something that is not only for beneficial purposes, but also for the excitement gained from making it. According to the theory of cognitive play, constructive play includes functional play. Constructive play involves the manipulation of physical objects to build or establish something. Constructive play activities are activities that can be done with friends the same age. This comprehensive tool is constructive game, meaning that this tool can be used in accordance with the wishes and creativity of children. This game can be fun too, as children can play with joy but they also learn about various cognitive concepts. With this tool, children also practice manipulating objects according to their imagination. They touch, hold and then make various designs or construct various forms as directed by the teacher or simply out of curiosity. This game is also used by children together with classmates or peers so that the tool is included in constructive play.

Table 1. Social-emotional Domain Ability in Children (Yusuf, 2014, 113-114)

\begin{tabular}{lll}
\hline Aspec & Behavior Caracteristic \\
\hline 1. Self-Awareness & a. Get to know and feel the emotion itself \\
& b. Understand the causes of the feeling \\
& c. Know the feeling and the effect of the actions \\
\hline 2. Managing emotions & a. Tolerate frustration and anger and to manage them better \\
& b. Can express anger appropriately without a fight \\
& c. Can control aggressive behavior of self destructive and others \\
& d. Have positive feelings about themselves, school and family \\
& e. Can deal with stress \\
& f. Can reduce feelings of loneliness and anxiety in the association \\
\hline 3. Utilize emotions & a. Have a sense of responsibility \\
productively & b. Can focus on the task \\
& c. Can control him/herself and not be impulsive \\
\hline 4. Empathy & a. Can accept others' viewpoints \\
& b. Have empathy or sensitivity to the feelings of others \\
& c. Can listen to others \\
\hline $5 . \quad$ Establish relationship & a. Can recognize and analyze the relationship with others \\
& b. Can resolve conflicts with others \\
& c. Can communicate with others \\
d. Have a friendly attitude or finds it easy to get along with friends \\
e. Have an attitude of tolerance and concern for others \\
f. Pay attention to social interests (love to help others) and can \\
g. Is happy sharing and working together \\
h. Is democratic in dealing with others
\end{tabular}


Educational games are games which are designed specifically for educational purposes. Educational games have some specific characteristics, namely:

a. These games can be used in various ways, the point is that these games can be used for various purposes, benefits and can be a variety of shapes (multi-purpose).

b. Intended primarily for preschool children that serve to develop various aspects of development as well as the child's motor skills.

c. Concerned about security both of form and material usage.

d. Can make children actively involved.

e. Are constructive and instructive.

Plaything comprehensively developed and used in the learning process based games comprehensively meets the characteristics of educational games, namely: the device is especially designed to support the learning process for children kindergarten group B with the concepts and objectives are deliberately made to improve the ability of the child in the cognitive and social-emotional. The process and the results of this tool are promoting security and safety for children at play. This security ranging from the material, how to make it to the final outcome of these games had the tests twice so that the tool is completely safe, convenient and can be used to improve children ability. The tool is also designed so that children can play actively, independently and creatively.

Traditional games are games that have been handed down from generation to generation. Often who created the game and when the game was created are unknown. Traditional games incorporate cultural values, such as training independent attitude, decision making, responsibility, honessty, control of attitude, helping each other, cooperating with others, defending the interests of the group (solidarity), democracy, and adherence to the rules among other values. An example of a traditional game is dominoes.

Plaything comprehensively resembles a game of dominoes shape and made of wood $15 \mathrm{~cm}$ long, $7.5 \mathrm{~cm}$ wide and $0.5 \mathrm{~cm}$ thick. Each face consists of two colors and the back brown wood. Each pair is numbered 20 color pieces. The concepts developed in the Tool Color Stick game, include: shape, color, size, classification and order, incorporating the concept of numbers, letters and symbols of mathematics. This tool contains elements of primary colors (red, yellow, blue, black and white), it contains elements numbers (numbers 1, 2, 3, 4, 5, $6,7,8,9,10)$, containing the alphabet letters from A to $\mathrm{z}$ (a, b, c, d, e, f, d, e, f, g, h, i, j, k, l, m, n, o, p, $\mathrm{r}, \mathrm{s}, \mathrm{t}, \mathrm{u}, \mathrm{w}, \mathrm{y}$ ), containing geometric shapes such as circles, triangles, rectangles, squares, cylinders, cubes and parallelograms and contains elements of mathematical operations, such as,,+- , and $\mathrm{x}$.

Installation of letters and numbers and mathematical symbols are arranged so that when playing can be paired with more flexibility. This tool is safe for both of form and use of the material and can make children actively involved and constructive.

This tool is safe and appropriate to the size of the child's hand and in accordance with the child's developmental level and age.

\section{RELEVANT RESEARCH}

- Based on research by Putri Admi Perdani (2014: 129-136), the results of the social skills of kindergarten class B increased by $42.13 \%$ from the average pre-intervention classes and $54.13 \%$ in post-test results. The study was conducted by the method of action research in Nurul'Ain kindergarten in Gue Gajah village, Aceh Besar from March to June, 2013.

- Research by Rosalina Dina (2008) linked constructive play with the creativity of children. The results found that there is a significant relationship between constructive play and the creativity of children.

- Ratna Istiarini (2015: 145-154) discovered that the ability to speak kindergartner beam B through play activities in groups showed an increase of scores from 73.75 to 90.25 into 81.25 to 96 overall score. The results obtained using action research methods class at the Bunga Hati Keluarga kindergarten, Tangerang District of academic year 2012/2013 (Ratna Istiarini, 2015: 145-154)

- The research results of Devinta Fistiani Norma (2013) found that there is no significant correlation between constructive play and increased creativity of children. $40 \%$ of subjects scored highly on creativity, but this percentage decreased to $33.3 \%$ after follow-up activities. This indicates that the level of creativity of the experimental group did not experience any significant increase.

- Su Tan Cheng and Li-Chun Chen (2014: 136) state that: 1) Picture books teaching enables students to perceive emotion, understand themselves more, and have good emotional awareness and expression, 2) Picture books 
teaching lets students with poor emotional control be willing to change, and provides a behavior example model to help students manage and control emotions, and 3) Picture books teaching provides students with a positive thinking attitude, interpersonal skills, and good emotion capacity utilization. The research subjects were 20 elementary school students of three grades in Kaohsiung City.

- Andrianus Krobo (2014: 25-34) put forward the idea that intrapersonal intelligence through activities plays a role early education. The research took place at Kartini SP 1 Kindergarten in Bumi Raya Village district of Nabire, Papua. The results showed that an increase in interpersonal intelligence related to internal aspects of the self, such as the feeling of life, the range of emotions, the ability to distinguish emotions and use them to guide and understand one's own behavior. These increases were analyzed by percentage, equal to $95.59 \%$. (Krobo, Andrianus, 2014: 25-34)

\section{Method}

The formative trial implementation of these tools was done in small groups during eight meetings in July and August 2015, and a large group of over 12 meetings in August and September 2015 in Fithria Islamic Kindergarten at Pondok Pinang III Street, Kebayoran Lama District, South Jakarta. Subjects in the test group are teachers and eight small children in group B and the subject is a large group of teachers with a class B group numbering 14 children. Analysis of data on the use of a game using a qualitative descriptive field notes and effectiveness percentage and analyzed by t-test to the results of the initial assessment and final assessment on the social-emotional abilities of children using socialemotional assessment instrument that has been developed previous researchers.

\section{RESULT AND DISCUSSION}

\section{Small Groups Trial}

The trial was conducted on 8 children from Group B 2 with Tri Rahayu as the teacher. All eight children were randomly selected from the 12 students who were in the group B2. All 12 children in class B2 were involved in the same learning activities, including the activity Stick Color, but only 8 of the children were used for this research. The research subjects were chosen at random.

The small group trials were conducted from August 3, 2015 until August 14, 2015. The learning activities carried out following the rotation centers.
This was done because Fithria Islamic Kindergarten apply learning centers with the system. Sentra owned by TK there are four centers, namely: preparation centers, beams centers, natural materials centers and IMTAQ centers (faith and religion). Each center is run by one teacher in charge. Meanwhile every teacher is responsible or become class guardian in one class only. Each class will be learning at the center on a daily basis and the distribution schedule classes to enter the center compiled every month by paying attention to the calendar and national holidays.

The effectiveness of a comprehensive learning game based on the achievement of emotional social abilities of children in group $\mathrm{B}$ refers to the achievement of competencies or indicators of emotional social abilities of children that have been formulated in the previous stage.

The result of the calculation of the initial assessment and the final score of the test results illustrate that the application of a small group-based learning model of comprehensive games can improve children's social-emotional skills in kindergarten group B. The improvement seen from the difference between initial and final assessment increased by 0.1 points or $4.88 \%$ up to 0.29 points or by $9.76 \%$.

The research discovered that there was one child named Je whose average score did not increase. This happened because when observed, Je was very quiet and was still attended by his mother in the classroom. It was also Je's first time in school so he hadn't had chance to make friends and adapt to the school environment. Besides that, Je rarely came into the classroom when the Colored Stick activity was being conducted, even though he was encouraged to participate. However, in general every child seemed to experience an increase in socialemotional abilities after this comprehensive gamebased learning activity.

The t-test results show a similar increase in the social-emotional abilities of the children. The average pairwise differences between pretest and posttest data shows there is a significant difference ( $\mathrm{p}$ value $<1 \%$ ) amounting to 0.383 points. This means that there is an increase in social-emotional abilities of children after the implementation of a comprehensive game-based learning. In other words, learning-based games comprehensively improved children's social-emotional skills in TK Group B on trial group was significantly smaller

\section{Large groups Trial}

The large group trial was conducted in class B1 with Salis Wiwitri as the teacher. Class B1 consisted of 14 children studying a. The trial program conducted on the prospective users of the program 
before the program is implemented in real learning situations. These large group trials were conducted at Fithria Islamic Kindergarten with teachers. These trials were conducted over 12 meetings (three times round the center) using a guide and comprehensive game-based learning tools. Experiments carried out in accordance with the lesson plan developed by the researchers. The data generated in the large group trial illustrates that the implementation of a comprehensive learning based games model improved the social-emotional skills of kindergarten children in group B. The improvements can be seen in the difference between the beginning and end assessment scores of each child. From 14 children, 11 children increased social-emotional abilities after comprehensive based learning games for 3 rounds centers. Socialemotional abilities increased in the children by between 0.05 points and 0.93 points or $1.63 \%$ and $30.83 \%$. Each child experienced an increase in socio-emotional abilities, though the amount of increase differed from child to child, most likely due to differing absorption rates of the children.

Comparison of the children's final assessment and initial assessment social-emotional abilities reveal that three children did not experience an increase in social-emotional abilities and some even received a final assessment score less than the initial assessment score. Those three children are F, J and M. It must be noted that just because the three children's scores did not improve, does not mean that the three children did not receive stimulation or arousal when playing the game Colored Stick.

In addition to the children having different absorption rates and learning styles, they have different characteristics. The three children were new students who entered Kindergarten B without entering Kindergarten A so they had missed out on crucial early childhood learning experiences. Additionally, they were still highly dependent on their parents or introduction.

Almost every day $\mathrm{F}$ and $\mathrm{J}$ had to be persuaded to go into the classroom and participate in the activities with their friends while $\mathrm{M}$ was frequently absent from school because no adult could take M to School. Other factors that can affect the increase in social-emotional abilities is children's attendance, learning experiences children have had before and the support of parents or family.

The result of the calculation of the $t$-test to test the mean paired difference between pretest and posttest data shows there is a significant difference ( $\mathrm{p}$-value $<1 \%$ ) amounting to 0.451 points. This means that there is an increase in social-emotional abilities of children after the implementation of a comprehensive game-based learning, or learning- based games can comprehensively improve TK Group B children's social-emotional skills in a large group.

The trial results of using the learning game Colored Stick in small and large groups is quite effective in helping children improve social and emotional abilities. This is consistent with the theory presented by Jackman Erikson that stated that the important thing in the playground is to help children develop friendly relations based on mutual trust. Erikson believed that children develop selfesteem and a sense of helplessness with the acquisition of the object. Hughes (cited in Hilda L Jackman, 2012: 21) strengthens Erikson's statement, namely, that play can also build ego functions as the development of physical and social skills and increase self-esteem. Lev Vigotsky states that "social experiences shape children's way of thinking and that social play offers children a way to interpret the world by focusing on rules that underlie all play activities and social interactions". The point is that the social experiences shape the way children think and that children's social play offers a way to interpret the world by focusing on the rules that underlie all play activities and social interaction. (Hilda L Jackman, 2012: 21)

A comprehensive game-based learning game called Colored Stick helps children develop social skills because the learning process is carried out in groups. Besides that, the child's emotional development is boosted as the game is very easy to use by children, so it helps children gain confidence and respect. Children will also not easily get frustrated because the concepts in the Colored Stick game are according to the age and development of children. Additionally, the children will learn patience because they have to wait for their turn to play. Overall, the results of this study illustrate that after following a comprehensive learning based game called Colored Stick, each child had an increase in the ability of social-emotional learning, especially if it is applied continuously and consistently throughout the school year progresses.

\section{REFERENCES}

Berk, Laura E. (2006). Child Development. Seven Ed., Boston: Pearson International Edition.

Cheng Su-Tan \& Chen Li Chun (2014). Picture Books teaching Elementary School Children to Enhance Emotional Intelligence. Prociding. The Pacific Early Childhood Education Research Association: Living In Harmony Through Early Childhood Education and care. 15 th Annual Conference August 8-10 2014 Bali- Indonesia. 
Devinta Norma F. (2013). Pengarub Permainan Konstruktif untuk Mengembangkan Kreativitas Anak Usia Sekolah: Artikel Publikasi Ilmiah. (Surakarta: Univ. Muhammadiyah Surakarta,).

Dina Rosalina (2018). Efektivitas Permainan Konstruktif terhadap Peningkatan Kreativitas Anak Usia Prasekolah. Surakarta: Fakultas Psikologi Univ Muhammadiyah Surakarta. http://etd.eprints.ums.ac.id/852/1/F10002018 6.pdf

Ernawulan Saodih (2015). Pengembangan Prilaku Sosial-Emosional Anak Taman Kanak-Kanak Melalui Layanan Bimbingan Konseling Perkembangan. Bandung: Direktori-FIP-Jur PGTK.

Goleman, Daniel (1995). Emotional Intelligence. Bloomsbury: Library of Unviolent Revolution.

Jackman, Hilda (2012). Early Education Curriculum: A Child's Connection to The World. Fifth Edition.USA: Wadsworth.

Krobo, Andrianus (2014). Peningkatan Kecerdasan Intrapersonal melalui Kegiatan bermain
Peran. Jurnal pendidikan Anak Usia Dini Volume 8 Edisi 1 April 2014. Jakarta: Universitas Negeri Jakarta.

Putri Admi Perdani (2014). Peningkatan Keterampilan Sosial Anak melalui Permainan Tradisional. Jurnal Pendidikan Anak Usia Dini. Volume 8 Edisi I. April 2014. ISSN: 1693-1602. Jakarta: Universitas Negeri Jakarta)

Ratna Istiarini (2014). Peningkatan Kemampuan Berbicara melalui Bermain Balok. Jurnal Pendidikan Anak Usia Dini. Volume 8 Edisi 1, April 2014. ISSN: 1693-1602. Jakarta: Universitas Negeri Jakarta.

Sri Tatminingsih (2016). Pengembangan Model Pembelajaran Berbasis Permainan Komprehensif untuk meningkatkan Kemampuan Kognitif dan Sosial-Emosional Anak TK. Disertasi. (Jakarta: Universitas Negeri Jakarta, 2016).

Syamsu Yusuf (2014).. Psikologi Perkembangan Anak dan Remaja. Bandung:Remaja Rosda Karya.

Photos from Sri Tatminingsih's collection (2019):

Physical model of coloured stick game equipment
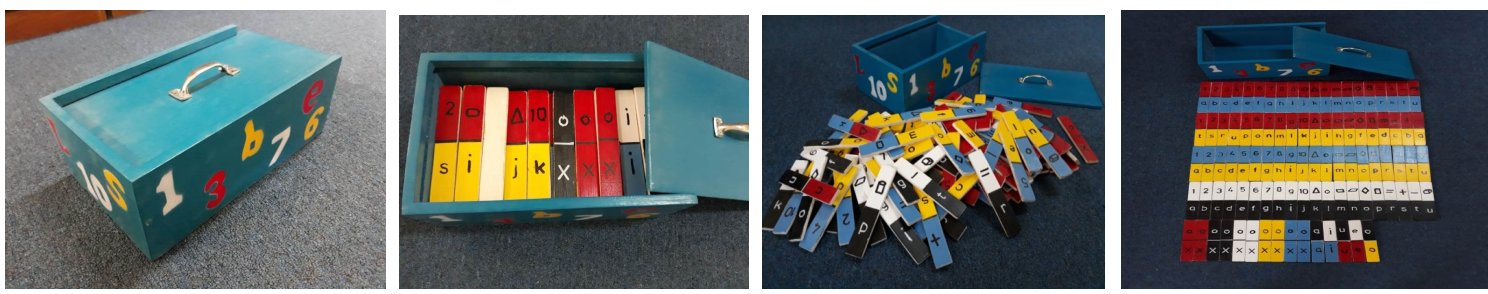

Examples of how to play colored sticks

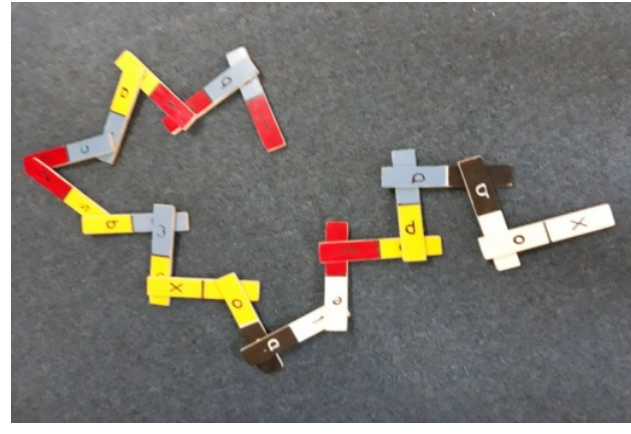

Colors recognition

Playing in groups

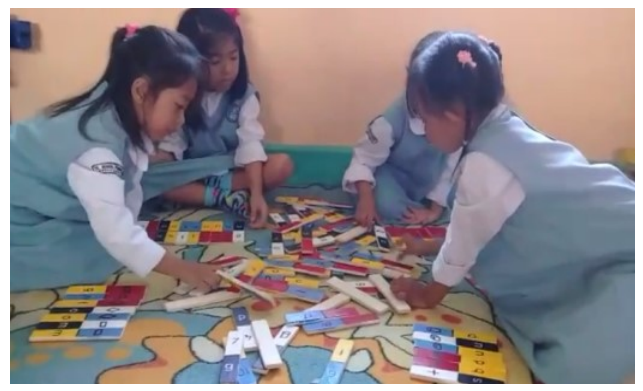

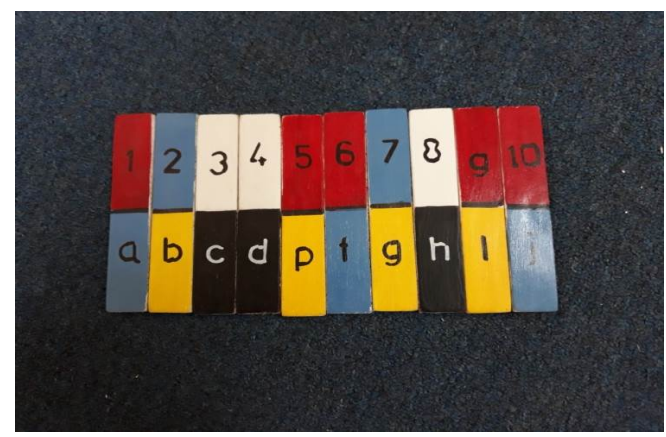

Sort numbers

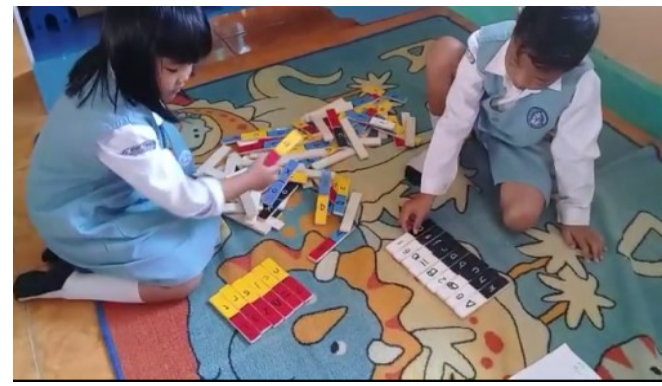

65 